\title{
THE EFFECTS OF COVID-19 PANDEMIC ON THE PREMATURE MORTALITY IN SERBIA IN 2020
}

\author{
Marko GALJAK \\ Demographic Research Centre, Institute of Social Sciences, Belgrade, e-mail: galjak@gmail.com
}

\begin{abstract}
Serbia is experiencing a massive number of deaths due to COVID-19. One way to express this mortality is by measuring the years of potential life lost to this disease. This paper looks at the cost of the pandemic in 2020 to premature deaths in Serbia. The final data on mortality in 2020 in Serbia provided by the Statistical Office of the Republic of Serbia is used to measure this loss. Premature mortality is examined through geographical, age, and sex dimensions. In total, 64.620 years of potential life were lost directly by COVID-19, i.e., 1019.14 years of potential life per 100000 people younger than 75. Men lost 2.5 as many potential years of life then women did. Moreover, the region of eastern and Southern Serbia fared much worse than any other region. There is no clear pattern regarding the rural/urban divide, as some of the hardest-hit municipalities were rural and urban. The analysis was expanded to include the estimate of the economic cost of premature mortality due to the COVID-19. In 2020 more than $\$ 0.34$ billion was lost to premature deaths, and by the end of 2021, this number will likely be well over $\$ 1$ billion when the pandemic ends. The direct cost of premature deaths on future birth rates will not be pronounced as very few women younger than 50 died to affect future birth rates significantly.
\end{abstract}

Keywords: YLPP, CLP, economic cost, mortality, deaths, SARS-CoV-2

Sažetak: Srbija ima ogroman broj umrlih od COVID-19. Jedan od načina da se izrazi ova smrtnost je preko indikatora izgubljenih godina potencijalnog života izgubljenog izazvane ovom bolešću. Ovaj rad razmatra cenu pandemije u 2020. godini izraženu kroz prevremenu smrt u Srbiji. Za merenje ovog gubitka koriste se konačni podaci o mortalitetu u 2020. godini u Srbiji Republičkog zavoda za statistiku. Prevremena smrtnost izazvana virusom korona se ispituje kroz geografsku, starosnu i polnu dimenziju. Ukupno je 64.620 godina potencijalnog života izgubljeno direktno od COVID-19, odnosno 1019,14 godina potencijalnog života na 100.000 ljudi mlađih od 75 godina. Muškarci su izgubili 2,5 puta više potencijalnih godina života nego žene u Srbiji. Region Istočne i južne Srbije prošao je mnogo gore nego bilo koji drugi region. Ne postoji jasan obrazac u pogledu podele ruralno/ urbano, pošto među najteže pogođenim opštinama ima i onih koje su ruralne i urbane. Analiza je proširena kako bi uključila procenu ekonomske cene prevremene smrtnosti usled COVID-19. Prve godine pandemije u Srbiji više od 0,34 milijarde američkih dolara izgubljeno je zbog prevremene smrti, a do kraja 2021. ovaj broj će verovatno biti mnogo veći. Do kraja pandemije ovaj broj će verovatno premašiti milijardu dolara. Direktni trošak prevremene smrti na buduće stope nataliteta neće biti izražen jer je veoma mali broj žena mlađih od 50 godina umrlo da bi značajno uticalo na buduće stope nataliteta.

Ključne reči: YLPP, CLP, ekonomski trošak, mortalitet, umrli, SARS-CoV-2. 


\section{INTRODUCTION}

The consequences of the coronavirus in Serbia are enormous. In 2020 alone, more than 10.356 people died from the coronavirus while the numbers for 2021 are probably significantly higher than it was in the first year of the pandemic (Marinković \& Galjak, 2021). Initial reports from the pandemic's start indicated that overall mortality was increasing by $10 \%$ due to the coronavirus (Potere et al., 2020). This relative, uniform increase in mortality in all age categories means that societies with many older people (such as Serbia) have a considerable number of deaths.

The mortality transition in Serbia has been occurring slowly, and premature mortality in the previous period was slow to converge with the most developed countries (Marinkovic, 2012). The COVID-19 pandemic only worsened the already unflattering mortality situation. The cost measured by the final death toll is unknown, as the pandemic is still ravaging Serbia. In 2020 alone, Serbia had lost 10.356 (SORS, 2021a), building up to a significant portion of severe excess mortality (Marinković \& Galjak, 2021).

Measuring the impact of a specific cause of death in years of potential life lost (YPLL) is well established and is often used in cases where that cause of death's impact on society, such as cancers (Guy \& Ekwueme, 2011), obesity (Konnopka et al., 2011), drugs (Smyth et al., 2007) and alcohol (Nelson et al., 2013). With COVID-19, whose impact there has been much research where YPLL was used to show its impact on premature mortality in the US to show racial, ethnic, and sex disparities (Bassett et al., 2020; Lilly et al., 2021; Pierce et al., 2021; Xu et al., 2021a, 2021b), in India to showcase the economic impact (Vasishtha et al., 2021) and Brazil to quantify the total mortality by regions (Castro et al., 2021).

In this paper, we use years of potential life lost (YPLL) to quantify the premature mortality caused by COVID-19 and show differences across municipalities of Serbia. We also discuss the gender gap in this premature mortality and its implications on the economy and natality.

\section{METHODS}

YPLL is an indicator of potentially lost years of life used to measure premature mortality in this paper. To calculate it, we need to select a reference age, which we would consider mortality premature. Usually, a reference age of 65 years (for countries with a high mortality rate that have not yet experienced a mortality revolution) or 75 years for developed countries with lower mortality rates and a longer life expectancy is taken to calculate the years of lost life. We get the most accurate results using the actual life expectancy, but the reference age can also be arbitrary, i.e., any 
absolute number. There has been some debate on the absolute versus relative approach (Mazzuco et al., 2021), but considering that the life expectancy in Serbia (for the total population) is just over 75 years (the three-year average for the years before the pandemic is 75.7), the reference length of life expectancy of precisely 75 years was chosen. In this way, it is possible to compare the relative results with the results from other countries that used this (most often used) reference age. The general formula for YPLL is given as:

$$
\left.Y P P L=\sum_{i=1}^{L}(L-i) \times d_{i}\right) \times \frac{100000}{N}
$$

Where:

$L$ - reference age

$d_{i-}$ number of those who died that are $i$ years old

$a_{i}$ - difference between referent age and age when the death occurred

$N$ - size of the population under the referent age $L$

To estimate the economic cost of premature mortality due to COVID19 , we can calculate the absolute number of YPLL using retirement age as reference age (for men and women) - known as years of potential productive life lost (YPPLL) and multiply it by the GDP per capita. This measure is also called the cost of productivity lost (CPL) (John et al., 2021; Najafi et al., 2016; Rumisha et al., 2020). The productive years lost to children under 15 who died (the minimum age for employment in Serbia), were calculated as the difference between the retirement age and the minimum age of employment rather than the actual age of death. While we could use a more sophisticated approach to estimate the productivity of the youngest, this is not warranted as the age distribution of those who died from COVID-19 is heavily skewed towards the older generations (number of people under 25 who died from this disease in 2020 was 15). CPL calculation can be expressed as:

$$
C P L=\left(\begin{array}{c}
\sum_{i=1}^{15}\left((65-15) \times d_{m i}\right)+\sum_{i=1}^{15}\left((63-15) \times d_{f i}\right) \\
\sum_{i=16}^{65}\left((65-i) \times d_{m i}\right)+\sum_{i=16}^{63}\left((63-i) \times d_{f i}\right)
\end{array}\right) \times G D P P C
$$

The final mortality data for 2020 was released on the 1st of July 2021 by the Statistical Office of the Republic of Serbia (SORS, 2021a). The detailed data on mortality (by the municipality) has been obtained through a special 
request from the Statistical Office of the Republic of Serbia (SORS). The municipality's estimated total (mid-year) population was obtained through the open data portal run by Statistical Office of the Republic of Serbia (SORS, 2021b).

\section{RESULTS}

The results of this study show that in Serbia, the number of years of potential life lost for all-cause mortality totaled 614.312 in 2020 . At the same time, 64.620 person-years lost were directly attributed to COVID19 (10.5\% of all years lost). Expressed as a relative number, that means 1019.14 years of potential life per 100.000 people younger than 75 were lost due to COVID-19. When we considered all the other causes in 2020, 9,688.45 years of potential life per 100.000 people younger than 75 were lost. In 2020 Serbia lost 1,286.96 years of potential life per 100.000 people younger than 75 more than in 2019, and the vast majority of these deaths happened due to COVID-19 (Figure 1). While the years of potential life due to indirect deaths that happened due to the pandemic are more challenging to measure, it is clear that not all of the excess premature mortality can be attributed directly to COVID-19. Without those direct COVID-19, the year 2020 is more similar to 2015 and 2017, both with particularly deadly seasonal influenza.

Figure 1 Years of potential life lost in Serbia (2017-2020)

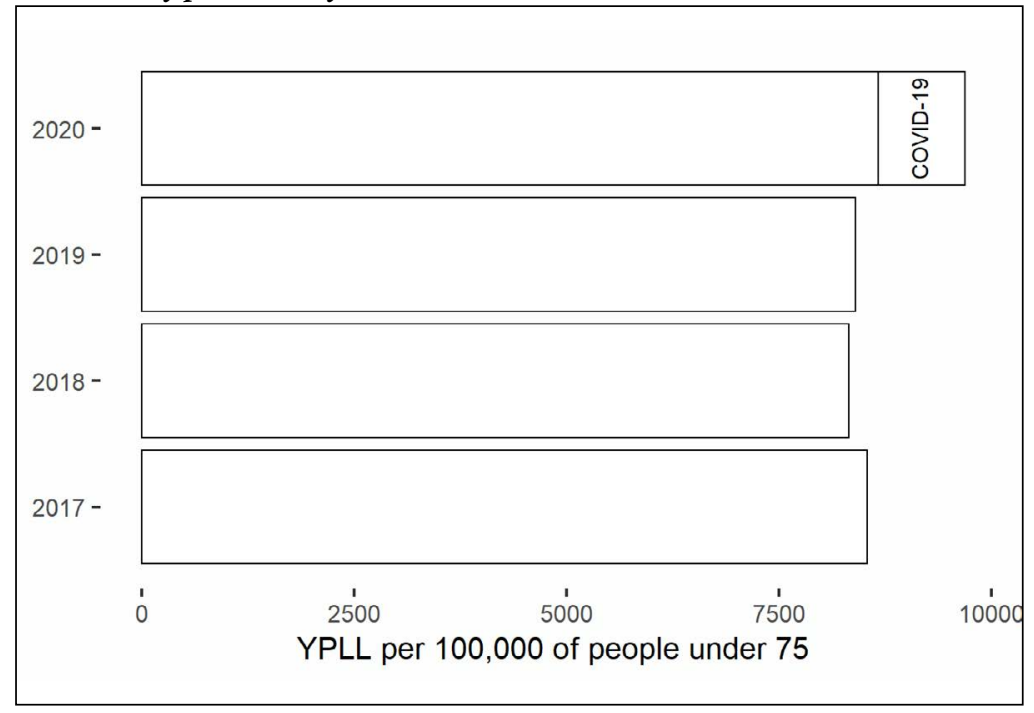


When these data are broken down by sex, the results confirm that there is a significant sex gap in person-years of potential life lost when it comes to COVID-19 in Serbia. The men of Serbia were much more impacted than women, as the number of potential years of life lost was 2.5 times higher for men who lost 46.023 years (1466.01 per 100000 men under 75) than women who lost 18.597 years (580.92 per 100000 women under 75). The fact that women are so much less likely to die prematurely from COVID-19 means that future birth rates cannot be significantly affected by it. In 2020 there were 117 women under 50 died from COVID-19, 40 were under 40 years old, and 20 were under 30 (under which age most of the births occur).

This excess premature mortality was not equally distributed across the municipalities of Serbia. Some municipalities were more heavily hit than others (Figure 2). As most of the excess premature mortality was attributable to covid-19 (Figure 1) when examining premature mortality variation, it is helpful to separate COVID-19 (Figure 3) and non-COVID-19 (Figure 4) mortality. Smaller municipalities tend to have more extreme values (either small or large). However, there are significant differences among the bigger municipalities. For example, the Belgrade municipality of Zvezdara lost 7 002.5 years while the municipality of Požarevac lost 12,495.8, a whopping $78.4 \%$ difference. The coefficient of variation was much higher when it came to COVID-19 mortality (CV=0.498) (Figure 3) than non-COVID-19 mortality $(\mathrm{CV}=0.200)$ (Figure 4$)$. However, the difference in variation of premature COVID-19 mortality is unknown and might be due to different factors such as access to adequate and timely healthcare, the spread of the SARS-CoV-2 virus, and the prevalence of preexisting conditions. Municipalities with the highest YPLL rate were Malo Crniće, Gadžin Han, Kostolac, Cuprija, and Crveni Krst municipality of Niš. In fact, when we look at the level of statistical regions, it is Southern and Eastern Serbia that has the most premature deaths due to COVID-19 with 1.350 YPLL per 100.000 inhabitants below 75, almost double that of Vojvodina (769 YPLL), and more than one quarter more than Šumadija and Western Serbia (. 069) and more than a third that of Belgrade region (954). 
Figure 2 Premature mortality in Serbia, 2020 - all causes

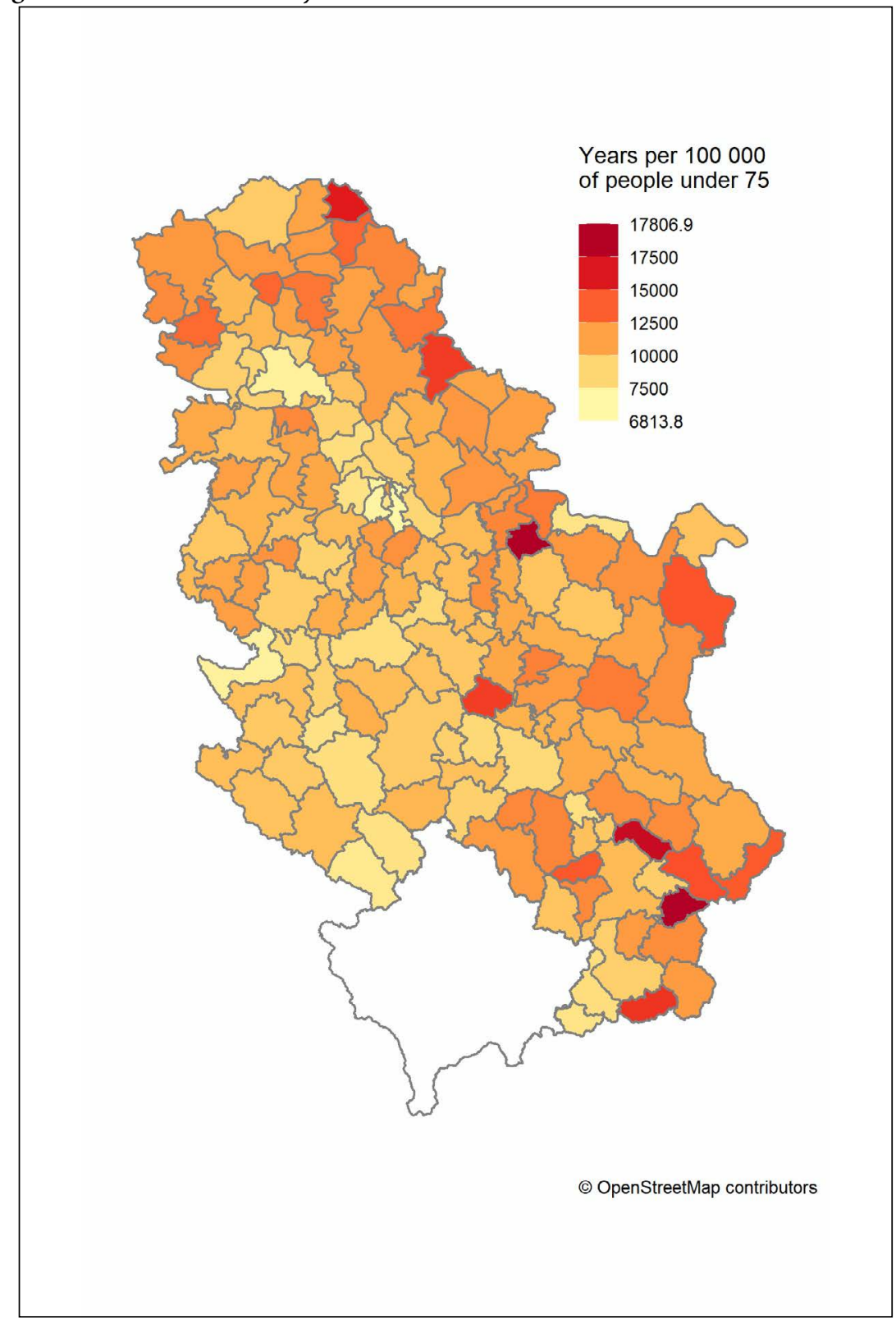


Figure 3 Premature mortality in Serbia, 2020 - COVID-19

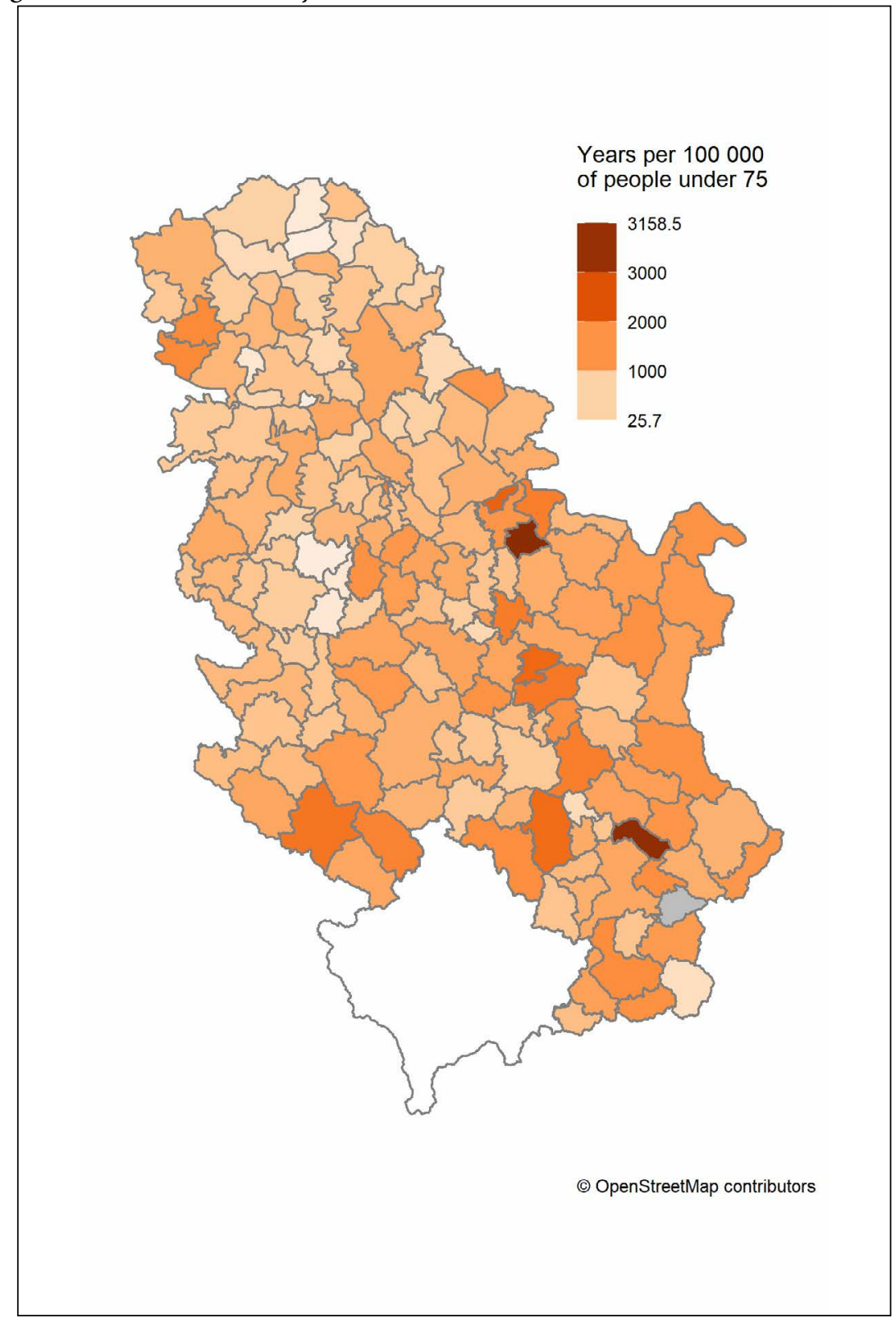


Figure 4 Premature mortality in Serbia, 2020 - all causes except for COVID-19

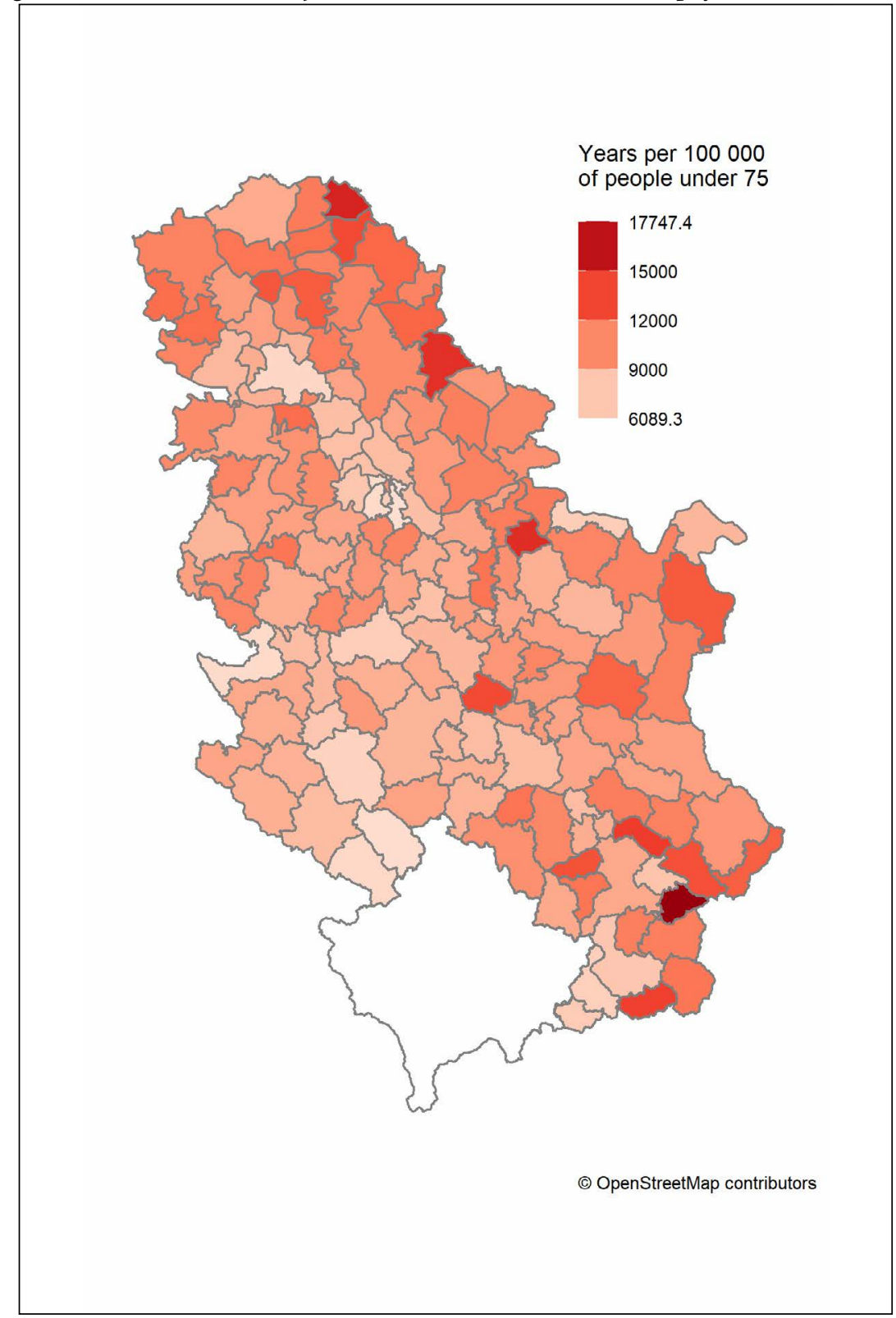


The economic cost of premature mortality is estimated at 44285 productive years of potential productive life (below the retirement age) lost directly to premature mortality due to COVID-19. Putting a monetary value to this loss provides us with an estimated 342088012 United States dollars ( $\$ 0.3$ billion) being lost directly to COVID-19 premature mortality. This number was calculated using the estimate of GDP per capita for 2020 (SORS, 2021c), and it represents the minimal possible cost as it does not take into account economic growth, reproductive potential, and other economic externalities.

\section{DISCUSSION}

The direct consequences of the COVID-19 pandemic are becoming more evident as time passes, as final and reliable data becomes available. In terms of the consequences to young lives, the number of years of potential life lost in absolute terms is riveting. This number can be expressed in terms of GDP and how big it will have for the future economy. The indirect consequences of mortality and related consequences of that mortality are more challenging to measure.

We would expect to see either complementarity or contrast when comparing COVID-19 premature mortality and non-COVID-19 premature mortality. In other words, we could expect to see either that those municipalities which suffered more premature deaths of COVID-19 had fewer non-COVID-19 premature deaths, as those young with preexisting conditions would have fallen to COVID-19 and not to their preexisting condition. The alternative would be a resemblance, as municipalities with low healthcare capacities (as reflected by YLPP) would also be bad at handling non-COVID-19 ailments. However, these COVID-19 and nonCOVID-19 YLPP rates are virtually orthogonal, i.e., completely uncorrelated $(\rho=-0.008, p=0.92)$. While some municipalities like Malo Crniće have very high COVID-19 and non-COVID-19 premature mortality, this does not generalize to the entire country.

The distribution geographic of premature deaths is somewhat worrying. There is no clear pattern regarding the rural/urban divide, as some of the most hit municipalities are rural, but we also observed that urban municipalities of Niš seem to have been walloped in terms of premature deaths. This points to a probable combination of multiple factors: how exposed the population has been to the virus, and the second is access to adequate healthcare. Of course, the factor that should never be forgotten is the data quality, which can be problematic, especially in smaller, more rural municipalities. Studies in the UK and the US confirmed that socioeconomic differences are drivers of diverse infection rates (Bassett et al., 2020; Niedzwiedz et al., 2020), so it is 
expected that there are similar disparities in Serbia. Further socioeconomic/ demographic analysis of premature mortality due to COVID-19 is needed to examine this.

Some of the Municipalities that have been strongly affected by COVID19 are air pollution hotspots as well. Future studies should look into the correlation between air pollution in Serbia and premature mortality due to COVID-19, as there has been some evidence that shows that air pollution increases infection rate and deaths rates due to COVID-19 (Cazzolla Gatti et al., 2020; Salamanca-Fernández et al., 2021; Sanchez-Piedra et al., 2021).

It would be interesting to see the interaction between municipality-level vaccination rates (general and younger people) and premature mortality for 2021, which will be possible once the final data on 2021 is released.

Any death is a personal tragedy in itself, but especially so when it comes to premature deaths. However, the economic cost of mortality is often overlooked. To calculate the actual economic cost of premature mortality is an impossible task. The estimate given in this paper of roughly $\$ 0.34$ billion assumes that the GDP per capita remains constant. If we consider the continued economic growth and other factors (such as wealth accumulation), then the economic cost of premature mortality due to COVID-19 is enormous. Given that the pandemic is not over yet, and that we do not have the reliable data for 202 yet, the total economic cost of the COVID-19 premature mortality in Serbia will likely be over $\$ 1$ billion.

The cost of premature deaths on birth rates, on the other hand, will probably not be that great. One of the most striking findings is the sex disparity when it comes to premature mortality. Although it has been known that men account for most COVID-19 deaths for some time now (Bienvenu et al., 2020), these differences are at least partially explained by hormonal differences between the sexes (Chanana et al., 2020). Men in Serbia die prematurely from COVID-19 at 2.5 times higher rates than women. Second, the number of women in the most fertile age who die from COVID-19 is too small to affect birth rates significantly. There were 117 women under 50 who died from COVID-19, and 40 were under 40 years old. The pandemic has brought many social changes, and though it can still leave a significant mark on crude birth rates during the crisis (Aassve et al., 2021; Ullah et al., 2020), it will be so in ways other than the direct effect of premature mortality.

\section{CONCLUSION}

Over the following years, there will probably be many more in-depth studies of each aspect of this pandemic, including premature deaths. The cost of the COVID-19 pandemic on premature mortality was grave in 
Serbia in 2020. One important thing to keep in mind is that we are currently operating with only one part of the multi-volume story that is the COVID19 pandemic. The toll the pandemic is taking in 2021 will be much bigger by all accounts than what it had transpired in 2020, and the question remains - when will the pandemic end? One thing is sure, the cost of the pandemic, though in many ways immeasurable, will be enormous in both personal and economic terms. Regional variations in the toll COVID-19 took are another thing to remember; as of 2020, the pandemic has not affected all municipalities equally. Will this be the case at the end of the pandemic is another open question? This paper starts the conversation about premature mortality and shows that YPLL can be a helpful tool to measure the costs of the COVID-19 pandemic.

This study was supported by the Open Society Foundation, Serbia as part of the project

"Serbia and Global Challenges: Towards Fairer and More Democratic Public Policies"

\section{REFERENCES}

Aassve, A., Cavalli, N., Mencarini, L., Plach, S. \& Sanders, S. (2021). Early assessment of the relationship between the COVID-19 pandemic and births in high-income countries. Proceedings of the National Academy of Sciences, 118(36), e2105709118. https://doi. org/10.1073/pnas.2105709118

Bassett, M. T., Chen, J. T. \& Krieger, N. (2020). Variation in racial/ethnic disparities in COVID-19 mortality by age in the United States: A cross-sectional study. PLOS Medicine, 17(10), e1003402. https://doi.org/10.1371/journal.pmed.1003402

Bienvenu, L. A., Noonan, J., Wang, X. \& Peter, K. (2020). Higher mortality of COVID19 in males: sex differences in immune response and cardiovascular comorbidities. Cardiovascular Research, 116(14), 2197-2206. https://doi.org/10.1093/cvr/cvaa284

Castro, A. P. B. de, Moreira, M. F., Bermejo, P. H. de S., Rodrigues, W. \& Prata, D. N. (2021). Mortality and Years of Potential Life Lost Due to COVID-19 in Brazil. International Journal of Environmental Research and Public Health, 18(14), 7626. https://doi. org/10.3390/ijerph18147626

Cazzolla Gatti, R., Velichevskaya, A., Tateo, A., Amoroso, N. \& Monaco, A. (2020). Machine learning reveals that prolonged exposure to air pollution is associated with SARSCoV-2 mortality and infectivity in Italy. Environmental Pollution, 267, 115471. https:// doi.org/10.1016/j.envpol.2020.115471

Chanana, N., Palmo, T., Sharma, K., Kumar, R., Graham, B. B. \& Pasha, Q. (2020). Sexderived attributes contributing to SARS-CoV-2 mortality. American Journal of Physiology-Endocrinology and Metabolism, 319(3), E562-E567. https://doi.org/10.1152/ ajpendo.00295.2020

Guy, G. P. \& Ekwueme, D. U. (2011). Years of Potential Life Lost and Indirect Costs of Melanoma and Non-Melanoma Skin Cancer: A Systematic Review of the Literature. PharmacoEconomics, 29(10), 863-874. https://doi. org/10.2165/11589300-000000000-00000 
John, D., Narassima, M. S., Menon, J., Rajesh, J. G. \& Banerjee, A. (2021). Estimation of the economic burden of COVID-19 using disability-adjusted life years (DALYs) and productivity losses in Kerala, India: a model-based analysis. BMJ Open, 11(8), e049619. https://doi.org/10.1136/bmjopen-2021-049619

Konnopka, A., Bödemann, M. \& König, H. H. (2011). Health burden and costs of obesity and overweight in Germany. The European Journal of Health Economics, 12(4), 345-352. https://doi.org/10.1007/s10198-010-0242-6

Lilly, D., Akintorin, S., Unruh, L. H., Dharmapuri, S., \& Soyemi, K. (2021). Years of potential life lost secondary to COVID-19: Cook County, Illinois. Annals of Epidemiology, 58, 124-127. https://doi.org/10.1016/j.annepidem.2021.03.005

Marinkovic, I. (2012). Prerana smrtnost: Potencijalno izgubljene godine života stanovništva Srbije, 1950-2010. In M. Rašević \& M. Marković, M. (Eds.), Pomeraćemo granice (pp. 9-24). Beograd: Institut društvenih nauka. ISBN 978-86-7093-141-1

Marinković, I. \& Galjak, M. (2021). Excess mortality in Europe and Serbia during the COVID-19 pandemic in 2020. Stanovništvo, 59(1). https://doi.org/10.2298/ STNV2101061M

Mazzuco, S. S., Suhrcke, M. M, \& Zanotto, L. L. (2021). How to measure premature mortality? A proposal combining "relative" and "absolute" approaches. Population Health Metrics, 19(1), 41. https://doi.org/10.1186/s12963-021-00267-y

Najafi, F., Karami-Matin, B., Rezaei, S., Khosravi, A. \& Soofi, M. (2016). Productivity costs and years of potential life lost associated with five leading causes of death: Evidence from Iran (2006-2010). Medical Journal of the Islamic Republic of Iran, 30, 412.

Nelson, D. E., Jarman, D. W., Rehm, J., Greenfield, T. K., Rey, G., Kerr, W. C., Miller, P., Shield, K. D., Ye, Y. \& Naimi, T. S. (2013). Alcohol-Attributable Cancer Deaths and Years of Potential Life Lost in the United States. American Journal of Public Health, 103(4), 641-648. https://doi.org/10.2105/AJPH.2012.301199

Niedzwiedz, C. L., O’Donnell, C. A., Jani, B. D., Demou, E., Ho, F. K., Celis-Morales, C., Nicholl, B. I., Mair, F. S., Welsh, P., Sattar, N., Pell, J. P. \& Katikireddi, S. V. (2020). Ethnic and socioeconomic differences in SARS-CoV-2 infection: prospective cohort study using UK Biobank. BMC Medicine, 18(1), 160. https://doi.org/10.1186/s12916-020-01640-8

Pierce, J. B., Harrington, K., McCabe, M. E., Petito, L. C., Kershaw, K. N., Pool, L. R., Allen, N. B. \& Khan, S. S. (2021). Racial/ethnic minority and neighborhood disadvantage leads to disproportionate mortality burden and years of potential life lost due to COVID-19 in Chicago, Illinois. Health \& Place, 68, 102540. https://doi.org/10.1016/j. healthplace.2021.102540

Potere, N., Valeriani, E., Candeloro, M., Tana, M., Porreca, E., Abbate, A., Spoto, S., Rutjes, A. W. S. \& Di Nisio, M. (2020). Acute complications and mortality in hospitalized patients with coronavirus disease 2019: a systematic review and meta-analysis. Critical Care, 24(1), 389. https://doi.org/10.1186/s13054-020-03022-1

Rumisha, S. F., George, J., Bwana, V. M. \& Mboera, L. E. G. (2020). Years of potential life lost and productivity costs due to premature mortality from six priority diseases in Tanzania, 2006-2015. PLOS ONE, 15(6), e0234300. https://doi.org/10.1371/journal. pone. 0234300 
Salamanca-Fernández, E., Rodríguez Barranco, M. \& Sánchez, M. J. (2021). [Influence of environmental temperature and air pollution on the transmission of SARS-CoV-2.]. Revista Espanola De Salud Publica, 95, e202101003.

Sanchez-Piedra, C., Cruz-Cruz, C., Gamiño-Arroyo, A.-E. \& Prado-Galbarro, F.-J. (2021). Effects of air pollution and climatology on COVID-19 mortality in Spain. Air Quality, Atmosphere \& Health, 14(11), 1869-1875. https://doi.org/10.1007/s11869-021-01062-2

Smyth, B., Hoffman, V., Fan, J. \& Hser, Y.-I. (2007). Years of potential life lost among heroin addicts 33 years after treatment. Preventive Medicine, 44(4), 369-374. https://doi. org/10.1016/j.ypmed.2006.10.003

SORS. (2021a). Vital events, 2020. Statistical Release, 180. https://publikacije.stat.gov.rs/ G2021/PdfE/G20211180.pdf

SORS. (2021b). Midyear population estimates (average). https://opendata.stat.gov.rs/data/ Wcf]sonRestService.Service1.svc/dataset/18010403IND03/3/csv

SORS. (2021c). Gross Domestic Product, 2020. https://web.archive.org/web/20211104181729/ https://publikacije.stat.gov.rs/G2021/HtmlL/G20211266.html

Ullah, Md. A., Moin, A. T., Araf, Y., Bhuiyan, A. R., Griffiths, M. D. \& Gozal, D. (2020). Potential Effects of the COVID-19 Pandemic on Future Birth Rate. Frontiers in Public Health, 8, 578438. https://doi.org/10.3389/fpubh.2020.578438

Vasishtha, G., Mohanty, S. K., Mishra, U. S., Dubey, M. \& Sahoo, U. (2021). Impact of COVID19 infection on life expectancy, premature mortality, and DALY in Maharashtra, India. BMC Infectious Diseases, 21(1), 343. https://doi.org/10.1186/s12879-021-06026-6

Xu, J. J., Chen, J. T., Belin, T. R., Brookmeyer, R. S., Suchard, M. A. \& Ramirez, C. M. (2021a). Racial and Ethnic Disparities in Years of Potential Life Lost Attributable to COVID-19 in the United States: An Analysis of 45 States and the District of Columbia. International Journal of Environmental Research and Public Health, 18(6), 2921. https:// doi.org/10.3390/ijerph18062921

Xu, J. J., Chen, J. T., Belin, T. R., Brookmeyer, R. S., Suchard, M. A. \& Ramirez, C. M. (2021b). Male-Female Disparities in Years of Potential Life Lost Attributable to COVID-19 in the United States: A State-by-State Analysis. Applied Sciences, 11(16), 7403. https://doi. org/10.3390/app11167403 


\title{
EFEKTI COVID-19 PANDEMIJE NA PREVREMENU SMRTNOST U SRBIJI 2020.
}

\author{
Marko GALJAK
}

\section{REZIME}

Srbija ima ogroman broj umrlih od COVID-19. Jedan od načina da se izrazi ova smrtnost je preko indikatora izgubljenih godina potencijalnog života izgubljenog izazvane ovom bolešću. Ovaj rad razmatra cenu pandemije u 2020. godini izraženu kroz prevremenu smrt u Srbiji. Za merenje ovog gubitka koriste se konačni podaci o mortalitetu u 2020. godini u Srbiji Republičkog zavoda za statistiku. Prevremena smrtnost izazvana virusom korona se ispituje kroz geografsku, starosnu i polnu dimenziju. Ukupno je 64.620 godina potencijalnog života izgubljeno direktno od COVID-19, odnosno 1019,14 godina potencijalnog života na 100.000 ljudi mlađih od 75 godina. Muškarci su izgubili 2,5 puta više potencijalnih godina života nego žene u Srbiji. Region Istočne i južne Srbije prošao je mnogo gore nego bilo koji drugi region, a Vojvodina, koja je imala skoro dvostruko manje izgubljenih godina potencijalnog života, najbolje. Ne postoji jasan obrazac u pogledu podele ruralno/urbano, pošto među najteže pogođenim opštinama ima i onih koje su ruralne (Malo Crniće) i urbane (poput centralnih opština Niša). Analiza je proširena kako bi uključila procenu ekonomske cene prerane smrtnosti usled COVID-19. Prve godine pandemije u Srbiji više od 0,34 milijarde američkih dolara izgubljeno je zbog prevremene smrti, a do kraja 2021. ovaj broj će verovatno biti mnogo veći. Do kraja pandemije ovaj broj će verovatno premašiti milijardu dolara. Direktni trošak prevremene smrti na buduće stope nataliteta neće biti izražen jer je veoma mali broj žena mlađih od 50 godina umrlo da bi značajno uticalo na buduće stope nataliteta. Tokom narednih godina, verovatno će biti mnogo više detaljnih studija o svakom aspektu ove pandemije, uključujući i aspekt prevremene smrtnost. Cena pandemije COVID-19 na preranu smrtnost bila je velika u Srbiji 2020. Jedna važna stvar koju treba imati na umu je da trenutno radimo samo sa jednim delom višetomne priče, a to je pandemija COVID-19. Danak koji pandemija uzima 2021. biće mnogo veći po svemu sudeći od onoga iz 2020. godine. Cena pandemije, iako na mnogo načina nemerljiva, biće ogromna. U ličnom ali i u ekonomskom pogledu. Ovaj rad započinje razgovor o prevremenoj smrtnosti i pokazuje da pokazatelj izgubljenih godina potencijalnog života može biti korisna sočiva za merenje troškova pandemije COVID-19 u Srbiji.

Ključne reči: YLPP, CLP, ekonomski trošak, mortalitet, umrli, SARS-CoV-2. 